\title{
TINJAUAN PENANGANAN PENYALAHGUNAAN IZIN TINGGAL KUNJUNGAN WARGA NEGARA ASING OLEH KANTOR IMIGRASI KELAS III NON TPP IMIGRASI BAUBAU TAHUN 2019 DALAM PERSPEKTIF KEAMANAN NASIONAL
}

\author{
${ }^{1}$ Faturachman Alputra Sudirman, ${ }^{2}$ Opi Purnama Zatun Bay Hamzah \\ 1,2 Universitas Halu Oleo \\ fatur@uho.ac.id \\ Kendari, 93231 ,Indonesia
}

\begin{abstract}
This study aims to identify and explain the forms of abuse of visit residence permits committed by foreign nationals in the working area of the Class III Non-Immigration Checkpoints Baubau; as well as describing the handling of abuse of residence permits visiting foreign nationals by the Immigration Office Class III Non-Immigration Checkpoints Baubau. Using qualitative research methods with an analysis of the national security approach. The results of the study show that throughout 2019 there were three forms of abuse of visit residence permits in the work area of the Baubau Immigration Office, namely overstaying, working in Indonesian territory without using a work visa, and marrying Indonesian citizens outside the applicable regulations in Indonesia. In dealing with the abuse of stay permits for visiting foreign nationals, the Baubau Immigration Office provides administrative sanctions in the form of deportation from the Indonesian Territory under Law Number 6 of 2011 concerning Immigration Article 75 Paragraph (2) letter $f$.
\end{abstract}

Keywords: Abuse of Visiting Stay Permits; Foreign Citizens; Handling; National Security

\begin{abstract}
Abstrak
Penelitian ini bertujuan untuk mengetahui dan menjelaskan bentuk-bentuk penyalahgunaan izin tinggal kunjungan yang dilakukan oleh warga negara asing di wilayah kerja Kantor Imigrasi Kelas III Non Tempat Pemeriksaan Imigrasi Baubau; serta menggambarkan penanganan penyalahgunaan izin tinggal kunjungan warga negara asing oleh Kantor Imigrasi kelas III Non Tempat Pemeriksaan Imigrasi Baubau. Menggunakan Metode penelitian kualitatif dengan analisa pendekatan Keamanan Nasional. Hasil penelitian menunjukan bahwa sepanjang tahun 2019 terdapat tiga bentuk penyalahgunaan izin tinggal kunjungan di wilayah kerja Kantor Imigrasi Baubau yakni overstay, bekerja di wilayah Indonesia tanpa menggunakan visa kerja dan melakukan pernikahan dengan Warga Negara Indonesia di luar peraturan yang berlaku di Indonesia. Dalam menangani penyalahgunaan izin tinggal kunjungan warga negara asing tersebut, Kantor Imigrasi Baubau memberikan sanksi administratif berupa deportasi dari Wilayah Indonesia sesuai dengan Undang-Undang Nomor 6 Tahun 2011 Tentang Keimigrasian Pasal 75 Ayat (2) huruf f.
\end{abstract}

Kata Kunci: Keamanan Nasional; Penanganan; Penyalahgunaan Izin Tinggal Kunjungan; Warga Negara Asing

Open Access at:http://ojs.uho.ac.id/index.php/PUBLICUHO/index

Journal Publicuho is licensed under a Creative Commons Attribution 4.0 International License. 


\section{Journal Publicuho}

ISSN2621-1351 (online), ISSN 2685-0729 (print)

Volume 4 Number 1 (February-April), (2021)pp.178-192

Accredited SINTA SK.NOMOR 28/E/KPT/2019

Open Access at:http://ojs.uho.ac.id/index.php/PUBLICUHO/index

DOI: 10.35817/jpu.v4i1.17202

\section{PENDAHULUAN}

Kemajuan pesat pada bidang teknologi informasi komunikasi serta transportasi yang merupakan ciri dari globalisasi memudahkan mobilitas perpindahan individu, barang, modal, serta jasa yang membuka kesempatan kerja ataupun tinggal di negara tujuan yang menjadi faktor penarik. Hal inipun berimplikasi bagi suatu negara untuk mengontrol mobilitas tersebut. Indonesia merupakan salah satu negara yang strategis bagi masuk dan keluarnya perpindahan orang karena tidak sedikit akses pintu untuk keluar dan masuk yang dapat dikontrol atau diawasi oleh pemerintahan melalui pintu gerbang resmi seperti pelabuhan, bandar udara, stasiun maupun perbatasan darat.

Menteri Hukum dan Hak Asasi Manusia menyebutkan bahwa tercatat hingga November 2019 total 23.036.342 WNA yang memasuki Indonesia. Rincian dengan jumlah Warga Negara Asing terbanyak yang masuk ke Indonesia di urutan pertama adalah China dengan jumlah 3.701.088 Warga Negara Asing termasuk jumlah kedatangan dan keberangkatan, diikuti dengan Australia, Malaysia, India, Jepang, Korea Selatan, Amerika Serikat, Inggris dan Prancis. Sedangkan, Tindakan Administrasi Keimigrasian yang paling banyak dilakukan yaitu kepada Warga Negara China dengan 709 orang, disusul dengan Bangladesh 384 orang, Afghanistan juga dengan 358 orang, Nigeria 353 orang dan terakhir Malaysia 175 orang. (Zuraya, 2019)

Besarnya jumlah WNA yang masuk ke Indonesia, maka dalam hal ini Imigrasi merupakan lembaga yang mengawasi masuknya orang ke dalam maupun ke luar Indonesia. Keimigrasian sebagaimana yang ditentukan adalah hal inwal lalu lintas orang yang masuk atau keluar wilayah Negara Republik Indonesia dan pengawasan orang asing di Indonesia. (UU Nomor 6 Tahun 2011 Tentang Keimigrasian Pasal 1 ayat (1) . Dalam pelaksanaannya sering kali ditemukan potensi pelanggaran izin keimigrasian, utamanya izin tinggal, kemudian orang asing yang tinggal di Indonesia namun tidak memiliki dokumen resmi atau secara sengaja melakukan perbuatan melanggar peraturan dalam kaitannya dengan keimigrasian. Berdasarkan hasil wawancara dengan Analis Keimigrasian Pertama yang menangani Warga Negara Asing di Kantor Imigrasi Kelas III Non TPI Baubau. Pada level daerah berdasarkan data yang ada menunjukkan bahwa sepanjang Tahun 2019 jumlah Warga Negara Asing yang masuk ke wilayah kerja Kantor Imigrasi Kelas III Non Tempat Pemeriksaan Imigrasi Baubau berjumlah 210 orang, dengan Warga Negara China yang menduduki jumlah tertinggi yakni berjumlah 93 orang. Kedatangan WNA masuk ke wilayah Indonesia terkhusus Kepulauan Buton dapat berpotensi melahirkan suatu persoalan jika tidak sesuai dengan Undang-Undang Nomor 16 Tahun 2011 tentang Keimigrasian di mana aktivitas WNA selama keberadaannya di Indonesia jika tidak sesuai dengan tujuan awal datang ke Indonesia dapat memicu masalah-masalah dalam pengawasannya, jika kegiatan tersebut dianggap 
ISSN2621-1351 (online), ISSN 2685-0729 (print

Volume 4 Number 1 (February-April), (2021)pp.178-192

Faturachman Alputra S., Opi Purnama Z Hamzah DOI: 10.35817/jpu.v4i1.17202

bertentangan atau mengancam keamanan nasional serta ketertiban umum atau tidak sesuai dengan peraturan yang ada.

Pelanggaran peraturan yang dilakukan oleh Warga Negara Asing seperti yang terjadi di Kabupaten Buton pada Januari 2019, di mana orang asing yang berasal dari Tiongkok masuk dan tinggal di Kabupaten Buton menggunakan bebas visa kunjungan yang hanya berlaku selama 30 hari. Namun, WNA Tiongkok tersebut melakukan kegiatan perdagangan dan pengambilan Sumber Daya Alam di Indonesia tanpa izin resmi dan visa yang digunakan telah habis masa berlakunya (overstay)( Ridho Aprizal Zawawi, 2019). Mendapat laporan dari masyarakat setempat, membuat pihak Kantor Imigrasi Kelas III Non TPI Baubau segera mengambil tindakan-tindakan penanganan pelanggaran terhadap WNA tersebut karena kedua wilayah tersebut masih masuk dalam wilayah kerja dari kantor ini.

Kemudian penyalahgunaan izin tinggal kembali terjadi pada bulan November 2019 di Kabupaten Buton Utara dimana Warga Negara Asing yang berasal dari Bangladesh tertangkap telah overstay di wilayah Indonesia dengan menggunakan bebas visa kunjungan yang hanya berlaku selama 30 hari dan tidak dapat diperpanjang, selain itu telah melanggar peraturan Undang-Undang Republik Indonesia Nomor 1 Tahun 1974 Tentang Perkawinan Pasal 60 Ayat (1) yang mengatur tentang perkawinan antara dua negara di mana perkawinan campuran tidak dapat dilaksanakan apabila persyaratan yang telah ditentukan oleh hukum pihak masing-masing belum terpenuhi. Namun, Warga Negara Bangladesh tersebut tidak mematuhi peraturan yang ada dan memilih untuk menikah siri tanpa sepengetahuan negara dan pihak keimigrasian serta tidak mematuhi persyaratan yang berlaku, kemudian melakukan tindakan melarikan diri dan membawa kabur uang dari mertua warga negara asing tersebut sejumlah Rp. 17.000.000, ketika akan diproses dan tindakan penanganan mulai dilakukan oleh pihak Kantor Imigrasi Kelas III Non TPI Baubau (Zawawi, 2020).

Apa yang telah dilakukan dua warga negara asing tersebut merupakan suatu pelanggaran dalam penyalahgunaan izin tinggal dan pelanggaran terhadap keamanan nasional karena setiap warga negara asing yang telah masuk ke wilayah Indonesia harus mengikuti peraturan yang ada di Indonesia serta tidak menimbulkan keresahan terhadap masyarakat, melanggar ketertiban umum, serta tidak merugikan Indonesia dan warga negara Indonesia. Berdasarkan poin pertama dalam selevtive policy bahwa hanya orang bermanfaat yang dapat masuk ke Wilayah Indonesia, dalam hal ini orang asing maupun investor yang datang ke Indonesia dapat meningkatkan devisa negara serta adanya inverstor yang masuk ke Indonesia dapat meningkatkan produktivitas di Indonesia, seperti dengan membuka perusahaan maupun pabrik yang sekaligus dapat menambah terbukanya lapangan pekerjaan bagi Warga Negara Indonesia. (Kantor Imigrasi Kelas III Non TPI Baubau, 2020). 


\section{Journal Publicuho}

ISSN2621-1351 (online), ISSN 2685-0729 (print)

Volume 4 Number 1 (February-April), (2021)pp.178-192

Accredited SINTA SK.NOMOR 28/E/KPT/2019

Open Access at:http://ojs.uho.ac.id/index.php/PUBLICUHO/index

DOI: 10.35817/jpu.v4i1.17202

Imigrasi memiliki beberapa fungsi, salah satu dari fungsi tersebut merupakan fungsi keamanan negara, oleh karena itu imigrasi memiliki beberapa tugas utama yang terkait dengan fungsi keamanan diantaranya menginvestigasi dan melaksanakan peran keimigrasian sesuai dengan perundang-undangan yang berlaku (investigation and law enforcement) serta bertugas untuk menjaga perbatasan (secure the border). Dari dua tugas utama dan fungsi imigrasi dapat dilihat bahwa tugas keimigrasian masuk dalam keamanan nasional bagian traditional issue. Namun seiring berkembangnya zaman maka setiap permasalahan negara juga berbeda pula, oleh karena itu lahir keamanan nasional modern atau yang lebih dikenal dengan Security Sector Reform, yang beberapa kontrol keamanan Negara dibawah kerangka sipil yang demokratis dalam hal ini Instansi Pemerintah.

Konsep keamanan memiliki dua pendekatan yakni pendekatan tradisional dan nontradisional. Dalam pendekatan tradisional fokus pada ancaman yang bersifat militer yang berasal dari luar (Sagena, 2019). Sedangkan, keamanan yang dilihat melalui pendekatan non-tradisional yaitu isu keamanan yang telah mengalami perkembangan berupa perluasan makna yang tidak hanya berorientasi pada militer saja, namun juga menyangkut isu-isu nonmilitary seperti aspek ekonomi, sosial, maupun lingkungan.

Penanganan yang dapat diambil oleh Kantor Imigrasi melalui pejabat keimigrasian dan pihak-pihak yang terkait berdasarkan peraturan dan Standar Operasional Prosedur (SOP) yang berlaku, yang kemudian pelaksanaannya dimuat kembali dalam bentuk Tindakan Administrasi Keimigrasian (TAK) Kantor Imigrasi Kelas III Non Tempat Pemeriksaan Imigrasi Baubau. Dasar hukum dari TAK tertuang dalam Pasal 75 ayat (2) Undang-Undang Nomor 6 Tahun 2011 tentang Keimigrasian. Tindakan Administratif Keimigrasian sebagaimana yang dimaksud pada ayat (1) dapat berupa: a). Pencatuman dalam daftar pencegahan atau penangkalan; b). Pembatasan, Perubahan, atau Pembatalan Izin Tinggal; c). Larangan untuk berada di satu atau beberapa tempat tertentu di Wilayah Indonesia; d). Keharusan untuk bertempat tinggal di suatu tempat tertentu di Wilayah Indonesia; e). Pengenaan biaya beban; dan/atau f). Deportasi dari Wilayah Indonesia.

Dalam hal ini, penanganan penyalahgunaan izin tinggal kunjungan oleh Warga Negara Asing memiliki Standar Operasional Prosedur (SOP) tersendiri yang tertuang dalam tahapan Tindakan Administratif Keimigrasian (TAK), adapun tahapannya meliputi 1). Pengolahan Hasil Pengawasan dan atau penyidikan.2). Pemeriksaan, 3) Penindakan.Dasar hukum dari tiga tahapan tersebut yaitu tercantum pada Undang-Undang Nomor 6 Tahun 2011 tentang keimigrasian pasal 75 ayat (1) bahwa pejabat imigrasi berwenang melakukan Tindakan Administrasi Keimigrasian (TAK) apabila ditemukan kegiatan berbahaya yang berpotensi membahayakan ketertiban umum atau tidak menaati perundang-undangan. 
ISSN2621-1351 (online), ISSN 2685-0729 (print

Volume 4 Number 1 (February-April), (2021)pp.178-192

Faturachman Alputra S., Opi Purnama Z Hamzah DOI: 10.35817/jpu.v4i1.17202

Pada dasarnya izin tinggal kunjungan yang diberikan kepada Warga Negara Asing dapat dikatakan sebagai penyalahgunaan izin tinggal kunjungan apabila warga negara asing tersebut tidak mematuhi peraturan dan ketentuan habis masa berlaku izin tinggal kunjungan yang terdapat pada setiap izin tinggal kunjungan yang dimiliki oleh warga negara asing tersebut, mengacu pada Peraturan Presiden Republik Indonesia Nomor 21 Tahun 2016 Tentang Bebas Visa Kunjungan Pasal 4 ayat (1) yakni, "Penerima Bebas Visa Kunjungan sebagaimana yang diaksud pada pasal 3 diberikan izin tinggal kunjungan untuk waktu paling lama 30 (tiga puluh) hari." Dan Peraturan Presiden Republik Indonesia Nomor 21 Tahun 2016 ayat (2) yakni, "Izin tinggal kunjungan sebagaimana yang dimaksud pada ayat (1) tidak dapat diperpanjang masa berlakunya atau dialih statuskan menjadi izin tinggal lainnya."

Studi mengenai pelanggaran izin tinggal oleh warga negara asing telah banyak dilakukan seperti (Muhlisa \& Roisah, 2020; Novarera, Rasito, \& Maryani, 2018; Setiawati, 2015). Namun penelitian pelanggaran izin tinggal oleh Warga Negara Asing yang mengambil studi di Kantor Imigrasi Kelas III Non TPI Bau-Bau belum pernah dilakukan sehingga studi ini dapat memberikan gambaran dalam penanganan penyalahgunaan izin tinggal oleh warga negara asing oleh kantor ini. Penelitian ini bertujuan untuk mengetahui bentuk-bentuk penyalahgunaan izin tinggal kunjungan yang dilakukan oleh warga negara asing di wilayah kerja Kantor Imigrasi Kelas III Non Tempat Pemeriksaan Imigrasi Baubau; serta mengetahui dan menjelaskan penanganan penyalahgunaan izin tinggal kunjungan warga negara asing oleh kantor ini dengan pendekatan Keamanan Nasional.

\section{METODOLOGI}

Metode Penelitian yang digunakan dalam riset ini ialah metode deskriptif dengan pendekatan-kualitatif. Adapun sumber data primer diperoleh dari hasil wawancara, dan data sekunder menggunakan dokumen laporan dari kantor imigrasi Kelas III Non TPI Baubau, jurnal, serta berita daring yang relevan dengan riset ini. Terkait dengan informan dalam penelitian ini dipilih berdasarkan pemahaman serta pengetahuan informan yang mendalam sehingga mampu memberikan data dan informasi terkait riset ini. Adapun informan tersebut Kepala Subseksi Teknologi Dan Informasi, Intelijen Dan Penindakan Keimigrasian, Staf Subseksi Teknologi Dan Informasi, Intelijen Dan Penindakan Keimigrasian, Staf Subseksi Pelayanan dan Verifikasi Dokumen Keimigrasian, Asmiruddin. Selanjutnya teknik analisis data yang digunakan ialah analisis model interaktif dari Miles, Huberman, \& Saldana dalam (Sudirman, Basri, Huda, \& Upe, 2020) yang terdiri dari pengumpulan data, reduksi data, penyajian data, serta simpulan. 


\section{Journal Publicuho}

ISSN2621-1351 (online), ISSN 2685-0729 (print)

Volume 4 Number 1 (February-April), (2021)pp.178-192

Accredited SINTA SK.NOMOR 28/E/KPT/2019

Open Access at:http://ojs.uho.ac.id/index.php/PUBLICUHO/index

DOI: 10.35817/jpu.v4i1.17202

\section{HASIL DAN PEMBAHASAN}

Visa On Arrival merupakan sebuah kebijakan terhadap WNA yang dapat mengajukan permohonan visa setelah sampai di Indonesia, yang bisa didapatkan di bandara atau pelabuhan laut tertentu yang memiliki fasilitas pelayanan VOA. VOA sendiri merupakan salah satu visa yang paling sering digunakan oleh para WNA yang berkunjung ke wilayah kerja Kantor Imigrasi di Baubau, dengan Total 40 WNA dari 14 Negara yang berbeda (Asmiruddin, 2020). Selain VOA, terdapat pula Bebas Visa Kunjungan yang sering digunakan Warga Negara Asing yang masuk ke Wilayah Kerja Kantor Imigrasi Baubau. Visa ini diberikan kepada WNA dengan memperhatikan selective policy yang berlaku di Indonesia. Pemegang visa ini dibebaskan dari kewajiban memiliki Visa Kunjungan ketika memasuki wilayah Indonesia. Bebas visa kunjungan berlaku selama tiga puluh hari dan tidak dapat diperpanjang masa berlakunya atau dialih statuskan ke izin tinggal. Secara umum, izin tinggal merupakan sebuah izin yang diberikan kepada Warga Negara Asing sesuai dengan Visa atau Izin Masuk yang dimilikinya. Di wilayah kerja Kantor Imigrasi Baubau tercatat terdapat tiga izin tinggal yang sering digunakan WNA sepanjang Tahun 2019, yaitu Izin Tinggal Kunjungan sebanyak 210 orang WNA, Izin Tinggal Terbatas sebanyak 40 orang dan Izin Tinggal Tetap berjumlah satu orang (Kantor Imigrasi Kelas III Non TPI Baubau, 2020a).

\section{Bentuk-Bentuk Penyalahgunaan Izin Tinggal Kunjungan Warga Negara Asing di Baubau Sepanjang Tahun 2019}

Berdasarkan hasil wawancara dengan petugas imigrasi yang menangani lalu lintas Warga Negara Asing di Kantor Imigrasi Baubau disebutkan bahwa, sepanjang Tahun 2019 terdapat 210 orang Warga Negara Asing yang masuk ke Baubau dengan berbagai tujuan kedatangan. Pada dasarnya, pemberian Izin Tinggal Kunjungan hanya diberikan oleh Pejabat Imigrasi setempat. Dalam pemberian Izin Tinggal Kunjungan, Pejabat Imigrasi menyesuaikan dengan izin masuk atau visa yang terdapat dalam paspor yang dimiliki oleh Warga Negara Asing tersebut. Izin Tinggal Kunjungan memiliki jangka waktu selama 30 hari dan dapat diperpanjang selama 4 kali dengan jangka waktu setiap perpanjangan yaitu 30 hari, selama Warga Negara Asing tersebut tidak melakukan pelanggaran di wilayah Indonesia.

Namun, sepanjang tahun 2019 tercatat bahwa terjadi penyalahgunaan Izin Tinggal Kunjungan yang dilakukan WNA di wilayah kerja Kantor Imigrasi Baubau, penyalahgunaan tersebut berupa :

\section{Overstay}

Overstay merupakan sebuah penyalahgunaan izin keimigrasian yang dilakukan oleh WNA dengan tetap berada di Wilayah Indonesia setelah masa izin tinggalnya habis. Setiap WNA akan dikenakan denda Overstay sesuai dengan ketentuan yang berlaku. 
ISSN2621-1351 (online), ISSN 2685-0729 (print

Volume 4 Number 1 (February-April), (2021)pp.178-192

Faturachman Alputra S., Opi Purnama Z Hamzah DOI: 10.35817/jpu.v4i1.17202

Sepanjang Tahun 2019 tercatat terdapat dua orang Warga Negara Asing yang overstay. pertama terjadi di bulan Januari 2019, overstay dilakukan oleh seorang Warga Negara China yang menetap di Desa Dongkala, Kecamatan Pasarwajo, Kabupaten Buton. Berdasarkan visa dan izin tinggal yang dimilikinya Warga Negara China bernama Lin Chengqin, memiliki masa berlaku sampai dengan tanggal 08 Januari 2019, sedangkan penangkapan terhadap pelaku berdasarkan laporan masyarakat dilakukan pada tanggal 12 Januari 2019. Oleh karena itu, pelaku overstay di Wilayah Indonesia selama empat hari dan dikenakan denda overstay sesuai ketentuan yang berlaku. Sebagaimana hasil wawancara dengan Kepala Subseksi Teknologi Informasi, Intelijen dan Penindakan Keimigrasian, Kantor Imigrasi Kelas III Non Tempat Pemeriksaan Imigrasi (Non TPI) Baubau berikut ini :

"Pada hari Sabtu 12 Januari, kami tim pengawasan dan penindakan keimigrasian Kantor Imigrasi Non TPI Baubau mendapatkan laporan dari masyarakat akan adanya kegiatan yang menyalahgunakan izin keimigrasian di salah satu pemukiman di desa di Kecamatan Pasarwajo, Kabupaten Buton. Mendapatkan laporan tersebut saya dan tim langsung merespon cepat dan kami langsung menuju TKP untuk melaksanakan pengintaian terlebih dahulu, setelah kami melihat memang benar ada orang asing dengan gelagat mencurigakan, kami beserta tim langsung berkoordinasi dengan Kepala Desa setempat untuk mendapatkan ACC dan setelah mendapatkannya kami dan Kepala Desa langsung menggrebek rumah yang bersangkutan. Setelah ditangkap dan dilakukan pemeriksaan dan BAP berdasarkan data yang ada, masa berlaku izin tinggalnya 08 Januari dan pelaku masih berada di Indonesia sampai penangkapan dilakukan, dan berdasarkan tanggal penangkapan yaitu 12 Januari maka WNA China itu sudah overstay selama empat hari di Wilayah Indonesia." (Zawawi, 2020)

Dalam proses penangkapannya, setelah mendapatkan informasi dari laporan masyarakat maka kantorpun terlebih dahulu akan melakukan pengintaian terhadap WNA tersebut yang diduga sebagai pelaku penyalahgunaan izin tinggal keimigrasian, kemudian mengawasi pergerakan dan tingkah laku pelaku. Setelah mengkonfirmasi berdasarkan hasil pengintaian dan pengawasan yang telah dilakukan bahwa benar Warga Negara Asing tersebut melakukan penyalahgunaan izin tinggal keimigrasian maka dilakukan penggrebekan terhadap pelaku setelah mendapatkan izin dari dari Kepala Desa setempat dan pelaku kemudian diamankan di Kantor Imigrasi Non TPI Baubau untuk menjalani proses pemeriksaan lebih lanjut untuk mengetahui apabila adanya pelanggaran lain yang dilakukan oleh pelaku di Wilayah Indonesia.

Overstay kedua dilakukan oleh seorang Warga Negara Bangladesh pada Bulan November 2019. Warga Negara Bangladesh yang menetap dan tinggal di Kelurahan Bangkudu, Kecamatan Kulisusu, Kabupaten Buton Utara. Berdasarkan visa dan izin tinggal yang dimilikinya, pelaku tercatat masuk ke Indonesia tanggal 18 Juni 2019 dan ditangkap pada tanggal 29 November 2019. Oleh karena itu, pelaku telah overstay di wilayah Indonesia selama 165 hari dan akan dikenakan denda overstay sesuai ketentuan yang berlaku. 


\section{Journal Publicuho}

ISSN2621-1351 (online), ISSN 2685-0729 (print)

Volume 4 Number 1 (February-April), (2021)pp.178-192

Accredited SINTA SK.NOMOR 28/E/KPT/2019

Open Access at:http://ojs.uho.ac.id/index.php/PUBLICUHO/index

DOI: 10.35817/jpu.v4i1.17202

Sebagaimana hasil wawancara dengan Petugas Imigrasi Subseksi Teknologi Dan Informasi, Intelijen Dan Penindakan Keimigrasian berikut ini :

"Tim wasdak mendapatkan informasi dari seorang informan bahwa ada seorang Warga Negara Asing yang tinggal di desa di Kabupaten Buton Utara yang keberadaannya sudah cukup lama. Berdasarkan informasi tersebut pada tangal 28 November 2019 tim melakukan pengintaian dan pengawasan terlebih dahulu ke Kelurahan Bangkudu, Kecamatan Kulisusu, Kabupaten Buton Utara. Kemudian pada tanggal 29 November 2019 setelah dilakukan pengintaian dan pengumpulan informasi dari masyarakat sekitar, tim memutuskan melakukan penggrebekan langsung di lokasi kejadian. Kemudian setelah penangkapan pelaku diamankan dan diperiksa, kami menemukan pelaku masuk ke Indonesia tanggal 18 Juni 2019 dan masih berada sampai November, total overstay pelaku yaitu selama 165 hari." (Hendriyanto, 2020)

Untuk proses penangkapan Warga Negara Bangladesh berdasarkan laporan seorang informan khusus yang dimiliki Kantor Imigrasi Non TPI Baubau, bahwa terdapat Warga Negara Asing yang menyalahgunakan izin tinggal keimigrasiannya dan telah bermukim di Wilayah Indonesia dalam jangka waktu yang cukup lama dari yang seharusnya. Hal tersebut kemudian di pastikan oleh Tim Kantor Imigrasi dengan melakukan pengintaian dan pengawasan dilingkungan sekitar tempat tinggal pelaku dan setelah ditemukan bukti yang cukup berdasarkan hasil pengintaian dan pengawasan maka pelaku segera diamankan oleh pihak Kantor Imigrasi Baubau untuk dilakukan proses pemeriksaan untuk mengetahui apabila adanya pelanggaran lain yang dilakukan Warga Negara Bangladesh tersebut.

\section{Bekerja di Wilayah Indonesia tanpa menggunakan Visa Kerja}

Pada penangkapan Warga Negara China yang melakukan overstay di Wilayah Indonesia, setelah menjalani proses pemeriksaan dan BAP ditemukan juga ditemukan bahwa WNA tersebut bekerja di Wilayah Indonesia tanpa memiliki Visa Kerja. Pekerjaan yang dilakukan WNA tersebut selama berada di Indonesia yaitu mengekspor cacing laut secara ilegal ke negara asalnya yakni China. Sebagaimana hasil wawancara dengan Kepala Subseksi Teknologi Informasi, Intelijen dan Penindakan Keimigrasian, Baubau berikut ini :

"Pelaku WNA China ini kasusnya mengekspor cacing laut atau yang orang sini (Baubau) bilang cacing penis atau juga cipou yang nanti akan diekspor ke China, permasalahan penyalahgunaan keimigrasian WNA China ini karena dia tidak menggunakan visa yang benar. Seharusnya dia menggunakan Visa Kerja." (Zawawi, 2020)

Pada proses penangkapan hingga pemeriksaan telah dikonfirmasi bahwa Warga Negara China tersebut menggunakan Bebas Visa Kunjungan sebagai bentuk izin keimigrasiannya ketika masuk ke Wilayah Indonesia, untuk Bebas Visa Kunjungan sendiri di khususkan kepada para WNA yang ingin melakukan kunjungan wisata ke Wilayah Indonesia dan memiliki masa berlaku selama 30 hari dan tidak dapat diperpanjang atau dialih statuskan menjadi izin keimigrasian lainnya. Namun, WNA China tersebut selama aktivitasnya di Indonesia pelaku 
ISSN2621-1351 (online), ISSN 2685-0729 (print

Volume 4 Number 1 (February-April), (2021)pp.178-192

Faturachman Alputra S., Opi Purnama Z Hamzah DOI: 10.35817/jpu.v4i1.17202

menyalahgunakan izin keimigrasian tersebut untuk bekerja dan melakukan ekspor ilegal yang dapat merugikan Indonesia di bidang perekonomian. Saat tim melakukan operasi terhadap pelaku dan menemukan barang bukti berupa cacing laut yang sedang diolah maupun yang siap ekspor secara ilegal ke China. Hal tersebut yang menjadi salah satu temuan bagi pihak Kantor Imigrasi Baubau untuk menjatuhkan sanksi terhadap pelaku.

\section{Melakukan pernikahan diluar Peraturan yang berlaku di Indonesia}

Setelah dilakukan pendalaman kasus dan BAP ditemukan bahwa Warga Negara Bangladesh yang ditangkap pada November 2019, telah menikahi seorang WNI di Kabupaten Buton Utara dan hal tersebut yang menjadi alasan terkuatnya untuk menetap di Indonesia dalam jangka waktu yang lama meskipun masa berlaku izin keimigrasiannya telah habis masa berlakunya. Dari segi peraturan perundang-undangan yang berlaku di Indonesia yaitu pada Pasal 8 Undang-Undang Nomor 6 Tahun 2011 Tentang Keimigrasian hal ini termasuk melanggar Undang-Undang Keimigrasian yang menetapkan bahwa Warga Negara Asing yang masuk ke Wilayah Indonesia wajib memiliki Dokumen Perjalanan yang sah dan masih berlaku.

Hal tersebut selaras dengan hasil observasi yang peneliti lakukan selama proses BAP yang dilakukan Petugas Imigrasi terhadap Warga Negara Bangladesh dan saksi yang merupakan seorang WNI yang menjadi istri dari WNA tersebut, telah mengakui bahwa telah dilangsungkannya pernikahan secara agama oleh kedua belah pihak tanpa mengikuti peraturan yang berlaku di Indonesia, khususnya peraturan yang mengatur tentang pernikahan campuran.

Hasil observasi peneliti diperkuat dengan hasil wawancara dengan Petugas Imigrasi Subseksi Teknologi Dan Informasi, Intelijen Dan Penindakan Keimigrasian yang bertugas melakukan BAP terhadap Warga Negara Bangladesh dan Saksi yang juga merupakan istri dari WNA tersebut, sebagai berikut :

"Setelah pendalaman kasus dalam hal ini dilakukan pemeriksaan dan BAP, kami menemukan juga bahwa orang Bangladesh ini menikah dengan salah seorang warga di Kabupaten Buton Utara, tapi pernikahannya tidak mengikuti prosedur yang semestinya dan peraturan perundang-undangan yang berlaku di Indonesia." (Hendriyanto, 2020)

Menurut peraturan Undang-Undang tentang perkawinan yang berlaku di Indonesia telah disebutkan bahwa perkawinan yang sah apabila dilakukan menurut hukum agama masingmasing dari kedua belah pihak dan tiap perkawinan yang dilangsungkan tercatat sesuai dengan peraturan perundangan yang berlaku ( Pasal 2 Undang-Undang Nomor 1 Tahun 1974 Tentang Perkawinan). Namun, Warga Negara Bangladesh tersebut dalam proses pemeriksaannya tidak memiliki dokumen-dokumen yang menunjukan bahwa pernikahan yang dilakukan dengan Warga Negara Indonesia sah di mata hukum yang berlaku di 


\section{Journal Publicuho}

ISSN2621-1351 (online), ISSN 2685-0729 (print)

Volume 4 Number 1 (February-April), (2021)pp.178-192

Accredited SINTA SK.NOMOR 28/E/KPT/2019

Open Access at:http://ojs.uho.ac.id/index.php/PUBLICUHO/index

DOI: 10.35817/jpu.v4i1.17202

Indonesia.

Persyaratan pernikahan campuran yang dilaksanakan di Indonesia yaitu untuk WNI tetap mengikuti persyaratan biasa pernikahan di Indonesia dan dari pihak WNA harus menyertakan Paspor, memiliki Certificate of No Impediment atau surat izin menikah dari kedutaan WNA tersebut, pihak WNI memberikan beberapa dokumen antara lain fotokopi Kartu Tanda Penduduk dan prenup jika ada ke kedutaan WNA tersebut, serta beberapa persyaratan lainnya. Oleh karena proses yang sangat panjang dan melibatkan dua peraturan negara, khususnya peraturan di Indonesia jika menjadi tempat dilangsungkannya pernikahan tersebut. Selain itu, berdasarkan Pasal 60 Undang-Undang Nomor 1 Tahun 1974 Tentang Perkawinan bahwa perkawinan tidak dapat dilangsungkan sebelum terbukti bahwa syarat yang berlaku dan telah ditentukan oleh masing-masing pihak telah terpenuhi. Hal ini menjadi salah satu faktor pendukung yang menjadi bahan pertimbangan Pejabat Imigrasi di Kantor Imigrasi Non TPI Baubau untuk memberikan sanksi terhadap Warga Negara Bangladesh

\section{Penanganan Penyalahgunaan Izin Tinggal Kunjungan Warga Negara Asing di Baubau Sepanjang Tahun 2019}

Pada dasarnya, ketika penyalahgunaan keimigrasian terjadi proses penanganan yang diambil merujuk pada Tindakan Administratif Keimigrasian seperti yang diatur pada Pasal 75 ayat (2) Undang-Undang Nomor 6 Tahun 2011 Tentang Keimigrasian. Adapun salah satu tindakan administratif keimigrasian yang diatur adalah deportasi dari Wilayah Indonesia.

Tindakan Administratif Keimigrasian dilakukan oleh pejabat imigrasi yang berwenang terhadap Warga Negara Asing yang melakukan tindakan yang melanggar peraturan dan ketentuan keimigrasian yang berlaku, melakukan kegiatan yang berbahaya dan diduga dapat membahayakan keamanan, merugikan negara dan masyarakat umum, mengacaukan ketertiban umum, serta tidak menaati peraturan perundang-undangan yang berlaku di Republik Indonesia. Selain itu, Tindakan Adminstratif Keimigrasian juga dilakukan terhadap Warga Negara Asing yang berada di Wilayah Indonesia untuk menghindarkan diri dari ancaman dan pelaksanaan hukuman di negara asalnya.

Dalam pengambilan keputusan Tindakan Adminitratif Keimigrasian oleh pejabat imigrasi kepada Warga Negara Asing harus dilakukan secara tertulis dan harus disertai dengan alasan yang jelas. Untuk itu, pejabat imigrasi khususnya pejabat imigrasi di bidang pengawasan dan penindakan keimigrasian melakukan kegiatan intelijen keimigrasian guna untuk mengumpulkan informasi terkait Warga Negara Asing tersebut

Setiap Warga Negara Asing yang memiliki izin tinggal namun masa izin tinggalnya telah berakhir masa berlakunya dan masih berada di Wilayah Indonesia kurang dari enam puluh hari dari batas waktu izin tinggal akan dikenai biaya beban sesuai dengan ketentuan 
ISSN2621-1351 (online), ISSN 2685-0729 (print

Volume 4 Number 1 (February-April), (2021)pp.178-192

Faturachman Alputra S., Opi Purnama Z Hamzah DOI: 10.35817/jpu.v4i1.17202

perundang-undangan, jika WNA tersebut tidak membayar biaya beban akan dikenai Tindakan Administratif Keimigrasian berupa Deportasi dan Penangkalan. Selain itu, jika terdapat WNA yang telah berakhir masa berlaku izin tinggalnya dan masih berada di Wilayah Indonesia lebih dari enam puluh hari dari batas waktu izin tinggal akan dikenai Tindakan Adminitratif Keimigrasian berupa Deportasi dan Penangkalan. Biaya beban yang wajib dibayarkan oleh Warga Negara Asing tersebut merupakan salah satu Penerimaan Negara, bukan Pajak di Bidang Keimigrasian.

Tindakan Administratif Keimigrasian diberlakukan dalam proses penanganan penyalahgunaan izin tinggal yang dilakukan seorang WNA asal China pada bulan Januari 2019. Setelah melakukan pemeriksaan melalui Berita Acara Pemeriksaan oleh Petugas Imigrasi kemudian dituangkan dalam Berita Acara Pendapat oleh Kepala Subseksi Teknologi Informasi, Intelijen dan Penindakan Keimigrasian, dan merujuk pada Peraturan tentang Tindakan Administratif Keimigrasian maka pelaku dikenakan Pasal 75 ayat (2) huruf $f$ yakni deportasi dari Wilayah Indonesia. Hasil sitaan yang ditemukan pada saat penangkapan pelaku menjadi Barang Sitaan Negara. Kegiatan pendeportasian Warga Negara China tersebut dilaksanakan oleh dua orang petugas imigrasi, Kepala Sub Seksi Teknologi Informasi, Intelijen dan Penindakan Keimigrasian dan Staf Sub Seksi Teknologi Informasi, Intelijen dan penindakan keimigrasian

Berdasarkan Atensi/Laporan Khusus Kantor Imigrasi Kelas III Non Tempat Pemeriksaan Imigrasi diketahui kegiatan pendeportasian tersebut dilakukan pada hari Senin, 28 Januari 2019 melalui Tempat Pemeriksaan Imigrasi Bandara Soekarno Hatta. Kegiatan pendeportasian tersebut juga dibantu oleh pejabat yang memberangatkatkan yaitu Supervisor Kantor Imigrasi Kelas I Khusus Soekarno Hatta.

Selain pada bulan Januari Tahun 2019, Tindakan Adinistratif Keimigrasian kembali dikeluarkan oleh Kantor Imigrasi Kelas III Non Tempat Pemeriksaan Imigrasi Baubau pada bulan Desember 2019, dimana terjadi penyalahgunaan izin tinggal kunjungan yang dilakukan oleh seorang Warga Negara Asing asal Bangladesh.

Setelah melakukan pemeriksaan melalui Berita Acara Pemeriksaan oleh Petugas Imigrasi kemudian dituangkan dalam Berita Acara Pendapat oleh Kepala Subseksi Teknologi Informasi, Intelijen dan Penindakan Keimigrasian, dan merujuk pada Peraturan tentang Tindakan Administratif Keimigrasian maka pelaku dikenakan Pasal 75 ayat (2) huruf f yakni deportasi dari Wilayah Indonesia. Hasil sitaan yang ditemukan pada saat penangkapan pelaku menjadi Barang Sitaan Negara.

Kegiatan pendeportasian Warga Negara Asing Bangladesh tersebut dilaksanakan oleh dua orang petugas imigrasi, yakni Kepala Sub Seksi Teknologi Informasi, Intelijen dan Penindakan Keimigrasian dan Muhammad Hendriyanto, dan Staf Sub Seksi Teknologi Informasi, Intelijen dan penindakan keimigrasian 


\section{Journal Publicuho}

ISSN2621-1351 (online), ISSN 2685-0729 (print)

Volume 4 Number 1 (February-April), (2021)pp.178-192

Accredited SINTA SK.NOMOR 28/E/KPT/2019

Open Access at:http://ojs.uho.ac.id/index.php/PUBLICUHO/index

DOI: 10.35817/jpu.v4i1.17202

Kegiatan pendeportasian tersebut dilakukan pada hari Senin, 22 Desember 2019 melalui Tempat Pemeriksaan Imigrasi Bandara Ngurah Rai Bali. Kegiatan pendeportasian tersebut juga dibantu oleh pejabat yang memberangatkatkan yaitu Supervisor Kantor Imigrasi Kelas I Khusus Ngurah Rai.

\section{Analisis Penanganan Penyalahgunaan Izin Tinggal Kunjungan Warga Negara Asing Melalui Pendekatan Keamanan Nasional}

Pada saat Reformasi 1998, Indonesia membangun sistem keamanan nasional yang baru atau dikenal dengan Security Sector Reform. SSR merupakaan sebuah keamanan nasional modern yang juga melibatkan sipil dalam kontrol keamanan negara dan dianggap lebih efisien. Ketentuan keamanan negara secara efektif dan efisien dalam kerangka kontrol sipil yang demokratis (Cottey, Edmunds, \& Forster, 2001). SSR juga melvas dan membawa keamanan nasional ke dalam level yang berbeda sesuai dengan perkembangan di dunia internasional bahwa keamanan saat ini tidak hanya konsep klasik keamanan negara saja, tetapi juga keamanan sosial dan keamanan manusia.

Akibat perkembangan di dunia internasional, setiap negara di dunia memiliki permasalahan keamanan nasional yang berbeda-beda. Barry (1991) menekankan tiga landasan keamanan nasional yaitu landasan ideasional terkait ide atau gagasan tentang wawasan kebangsaan, landasan fisik terkait dengan penduduk, wilayah maupun sumber daya yang terletak dalam otoritas teritorial, dan landasan institusional yaitu berkaitan dengan mekanisme kenegaraan termasuk lembaga dari eksekutif maupun ketentuan hukum, prosedur dan norma-norma kenegaraan. Lembaga pemerintahan yang berwenang dan mengatur keluar masuknya WNA di Wilayah Indonesia adalah Imigrasi. Setiap wilayah di Indonesia memiliki Kantor Imigrasi yang masing-masing memiliki wilayah kerjanya sendiri, termasuk Kantor Imigrasi di Baubau.

Kantor Imigrasi Kelas III (Non TPI) Baubau memiliki 6 Kabupaten/Kota sebagai bagian dari wilayah kerjanya, berbagai sumber daya alam serta sektor pariwisata yang dimiliki oleh masing-masing daerah tersebut telah menarik minat Warga Negara Asing untuk berkunjung maupun melakukan investasi di berbagai bidang. Keluar masuknya Warga Negara Asing di Wilayah Indonesia dengan tetap memerhatikan kebijakan Selective Policy yang berlaku di Indonesia sehingga kepentingan nasional tetap tercapai. Sebagai salah satu lembaga pemerintahan negara dalam menangani segala sesuatu yang terkait dengan WNA, imigrasi juga melakukan pengawasan dan penindakan terhadap WNA yang dianggap dapat mengancam keamanan nasional Indonesia, hal ini sesuai dengan kajian Anggoro (2003) yang menekankan bahwa keamanan nasional sebagai kemampuan suatu bangsa untuk melindungi nilai-nilai internalnya dari ancaman luar.

Warga Negara Asing dikategorikan sebagai ancaman dari luar dalam suatu negara karena 
ISSN2621-1351 (online), ISSN 2685-0729 (print

Volume 4 Number 1 (February-April), (2021)pp.178-192

Faturachman Alputra S., Opi Purnama Z Hamzah DOI: 10.35817/jpu.v4i1.17202

setiap WNA yang masuk ke Indonesia wajib menaati setiap peraturan perundang-undangan yang berlaku di Indonesia, tidak menggangu ketertiban umum serta tidak mengancam keamanan nasional Indonesia. Namun, pada penyalahgunaan izin tinggal kunjungan yang dilakukan oleh dua orang WNA dari China yang overstay, dalam hal ini telah melanggar peraturan yang berlaku di Indonesia dan bekerja di Wilayah Indonesia tanpa memiliki Visa Kerja dan mengekspor sumber daya alam Indonesia kembali ke negaranya secara ilegal, hal ini merupakan salah satu bentuk ancaman terhadap keamanan nasional seperti yang studi Kapstein (1992) bahwa aspek-aspek lain yang berkaitan dengan kehidupan manusia juga penting dalam hal keamanan dan ketersediaan sumber daya ekonomi, stabilitas, lembaga dan hubungan-hubungan untuk menyediakan tingkat kesejahteraan yang memadai. Selanjutnya, pada penyalahgunaan yang kedua dilakukan oleh WNA asal Bangladesh dengan overstay dan menikah tanpa mematuhi persyaratan yang terdapat dalam Undang-Undang yang berlaku di Indonesia. Kedua penyalahgunaan ini jelas tidak sesuai dengan peraturan perundang-undangan yang berlaku di Indonesia, karena keamanan juga mencakup masalah keamanan sosial (Barry, 1991)

Sebagai lembaga pemerintahan negara yang berwenang melakukan penanganan terhadap WNA yang telah melakukan penyalahgunaan dengan memberikan Tindakan Administratif Keimigrasian yaitu deportasi dari Wilayah Indonesia, sesuai dengan peraturan perundang-undangan yang berlaku di Indonesia. Hal ini memperlihatkan bahwa penyelenggaraan keamanan nasional bukan lagi hanya mengandalkan aktor-aktor penyelenggaraan keamanan nasional tetapi juga melibatkan lembaga keamanan dan institusi pemerintahan lainnya (Mukhtar, 2017). Penanganan yang dilakukan oleh Kantor Imigrasi Baubau, menunjukkan bahwa keamanan nasional tidak lagi menyangkut tentang militer saja tetapi terdapat pula aspek non militer yang dapat menjadi faktor ancaman terhadap keamanan nasional Indonesia yang berkembang sesuai dengan situasi dari dunia internasionsal. Selain itu, menunjukkan juga reformasi keamanan nasional Indonesia dilakukan dengan menempatkan lembaga pemerintahan yang telah memiliki tupoksi kerja dan wewenangnya masing-masing, namun masih tetap berada dibawah kontrol negara dalam mengatur keamanan nasional Indonesia 


\section{Journal Publicuho}

ISSN2621-1351 (online), ISSN 2685-0729 (print)

Volume 4 Number 1 (February-April), (2021)pp.178-192

Accredited SINTA SK.NOMOR 28/E/KPT/2019

Open Access at:http://ojs.uho.ac.id/index.php/PUBLICUHO/index

DOI: 10.35817/jpu.v4i1.17202

\section{KESIMPULAN}

Sepanjang Tahun 2019, tercatat terjadi tiga bentuk penyalahgunaan Izin Tinggal Kunjungan yang dilakukan Warga Negara Asing di wilayah kerja Kantor Imigrasi Kelas III (Non TPI) Baubau, sebagai berikut; Overstay pertama dilakukan oleh seorang Warga Negara China di Desa Dongkala, Kecamatan Pasarwajo, Kabupaten Buton selama empat hari. Overstay kedua dilakukan oleh seorang Warga Negara Bangladesh di Kelurahan Bangkudu, Kecamatan Kulisusu, Kabupaten Buton Utara selama 165 hari. Kedua, Bekerja di Wilayah Indonesia tanpa menggunakan Visa Kerja, penyalahgunaan ini dilakukan oleh Warga Negara China yang melakukan ekspor cacing laut secara illegal ke Negara asalnya. Ketiga, Melakukan Pernikahan diluar Peraturan yang Berlaku Di Indonesia, penyalahgunaan ini dilakukan oleh Warga Negara Bangladesh yang melakukan pernikahan dengan seorang Warga Negara Indonesia di Kabupaten Buton Utara. Sebagai bentuk upaya melindungi keamanan nasional dalam penanganannya terhadap penyalahgunaan Izin Tinggal Kunjungan sepanjang Tahun 2019, Kantor Imigrasi Baubau memutuskan menjatuhkan sanksi administratif terhadap Warga Negara China dan Warga Negara Bangladesh tersebut. Sanksi administratif tersebut berupa Tindakan Administratif Keimigrasian Pasal 75 Ayat 2 Huruf (f) yakni Deportasi dari Wilayah Indonesia dalam Undang-Undang Nomor 6 Tahun 2011 Tentang Keimigrasian. Kegiatan pendeportasian Warga Negara China dilakukan pada tanggal 28 Januari 2019 melalui Bandara Udara Soekarno-Hatta dan kegiatan pendeportasian Warga Negara Bangladesh dilakukan pada tanggal 22 Desember 2019 melalui Bandara Ngurah Rai Bali.

\section{DAFTAR PUSTAKA}

Anggoro, K. (2003). Keamanan nasional, pertahanan negara, dan ketertiban umum. Seminar Pembangunan Hukum Nasional VIII. Denpasar: Badan Pembinaan Hukum Nasional, Departemen Kehakiman Dan HAM RI.

Asmiruddin. (2020). Wawancara Petugas Imigrasi Subseksi Pelayanan dan Verifikasi Dokumen Keimigrasian Kantor Imigrasi Kelas III Non TPI Baubau. Baubau.

Barry, B. (1991). People, states and fear: An agenda for international security studies in the post-Cold War era. Dorchester: Pearson-Longman.

Cottey, A., Edmunds, T., \& Forster, A. (2001). Democratic control of the military in postcommunist Europe: Guarding the guards. Springer.

Hendriyanto, M. (2020). Wawancara Petugas imigrasi Subseksi Teknologi Dan Informasi, Intelijen Dan Penindakan Keimigrasian Kantor Imigrasi Kelas III Non TPI Baubau. Baubau.

Kantor Imigrasi Kelas III Non TPI Baubau. (2020a). Laporan Statistik Izin Tinggal Berdasarkan Kebangsaan Kanim Kelas III Non TPI Baubau. Baubau.

Kantor Imigrasi Kelas III Non TPI Baubau. (2020b). Optimalisasi Tim Pengawasan Orang Asing Dalam Rangka Penegakan Hukum Keimigrasian. 
Kapstein, E. B. (1992). The political economy of national security: A global perspective. McGraw-Hill Humanities, Social Sciences \& World Languages.

Muhlisa, A. N., \& Roisah, K. (2020). Penegakan Hukum Keimigrasian Terhadap Penyalahgunaan Visa Izin Tinggal Kunjungan Lewat Batas Waktu (Overstay) Pada Warga Negara Asing. Jurnal Pembangunan Hukum Indonesia, 2(2), 145-157.

Mukhtar, S. (2017). KEAMANAN NASIONAL: ANTARA TEORI DAN PRAKTEKNYA DI INDONESIAI. Sociae Polites, 127-137.

Novarera, H., Rasito, R., \& Maryani, M. (2018). Pelanggaran Keimigrasian yang Di Lakukan Oleh Warga Negara Asing (Wna)(Studi Kasus Kantor Imigrasi Kelas I Jambi). UIN Sulthan Thaha Saifuddin Jambi.

Sagena, U. W. (2019). Memahami Keamanan Tradisional dan Non-tradisional di Selat Malaka: Isu-isu dan Interaksi antar Aktor. Jurnal Hubungan Internasional Interdependence, 1 (1).

Setiawati, D. (2015). Penegakan Hukum Terhadap Warga Negara Asing (WNA) yang Melanggar Izin Tinggal (Overstay). Pandecta Research Law Journal, 10(1).

Sudirman, F. A., Basri, M., Huda, K., \& Upe, A. Collaborative Governance Dalam Pelaksanaan Program Keluarga Harapan (Pkh) Sebagai Upaya Pencapaian Sustainable Development Goals (Sdgs). Jurnal Neo Societal, 5(4), 381-394..

Zawawi, R. A. (2020). Wawancara Kepala Subseksi Teknologi Dan Informasi, Intelijen Dan Penindakan Keimigrasian.Kantor Imigrasi Kelas III Non TPI Baubau. Baubau.

Zuraya, N. (2019). 3,7 Juta Warga China Lintasi Indonesia Sepanjang 2019. Retrieved March 5, 2021, from Republika.co.id website: https://nasional.republika.co.id/berita/q3680r383/37-juta-warga-china-lintasiindonesia-sepanjang-2019 